\title{
Memória da música popular brasileira e agenciamentos da vida social
}

\author{
Mozahir Salomão Bruck
}

\section{Considerações táticas}

rtistas do universo da música - cantores, compositores, letristas, instrumen-
tistas e maestros - e a própria música tornaram-se, nas décadas mais recentes,
no Brasil, cobiçados e recorrentes atores a protagonizarem narrativas de natureza memorialística. Alude-se aqui ao expressivo acervo de biografias, romances, livros-reportagem, song-books, documentários audiovisuais, além de musicais e peças de teatro, entre tantos outros, que têm alimentado e retroalimentado o que se pode perceber como uma profícua indústria da memória coletiva musical. E tem sido assim, mais fortemente, a partir da segunda metade do século XVIII, quando os músicos, no mundo ocidental, superaram a posição social de criadagem que ocupavam para tornarem-se tão importantes quanto a música que produziam (Blanning, 2011). E se as músicas acabam por referenciar distintas épocas da vida social, também elas próprias foram resultado e expressão do que se viveu nessas distintas temporalidades.

Interessa-nos, neste artigo, o que nos parece ser uma instigante refração da cultura brasileira - a visada através de movimentos e gêneros musicais na qual momentos, circunstâncias, espaços e agenciamentos sociais são recuperados/reconstruídos por meio de narrativas memorialísticas. Para tanto, optamos por trabalhar com quatro livros que, cobrindo um período de aproximadamente sete décadas (1940-2010), buscam oferecer um olhar pormenorizado sobre aspectos diversos da vida social brasileira, percebidos a partir dos contextos da produção e circulação de gêneros musicais que tiveram grande sucesso comercial e inegável aceitação por parte do público. Narrativas em que estão presentes muitos dos elementos carac- 
terísticos dos relatos memorialísticos: a essência pela borda, o universal contido no singular, a desmaterialização de certezas ou, em alguns casos, o ingênuo reforço à manutenção de mitos que, na sua existência lacunar de sentidos e na ausência de argumentos que definitivamente os refutem, acabam por sobreviver. E sobrevivem valendo-se também dessa natureza fluida da memória, sempre resultado de intermináveis negociações e disputas.

Nessa dimensão empírica, foram eleitos para análise quatro livros lançados a partir do início da década de 1990, sendo dois deles em 2015: Chega de saudade (Ruy Castro, 1990); Eu não sou cachorro não (Paulo César de Araújo, 2002); Cowboys do asfalto (Gustavo Alonso, 2015) e A noite do meu bem (Ruy Castro, 2015). Bossa-nova, brega, sertanejo e samba-canção: gêneros musicais que, a seu modo, influenciaram a vida de gerações de brasileiros e que também, do seu jeito, impactaram afetiva e efetivamente a vida cultural e social do País. Daí, sua relevância e potência heurística como objeto de memória, desvelador de circunstâncias históricas, modos de agir, (des)regramentos morais e tantos outros aspectos que marcaram concretamente a vida, em décadas passadas, de famosos e anônimos, poderosos e destituídos e de artistas nem exatamente tão talentosos, mas que se eternizaram na memória e no coração do povo, ou gênios que morreram praticamente desconhecidos.

A aproximação de tais relatos teve como orientação principal perceber como esses autores articularam aspectos da memória social, enredando documentos históricos, história oral, filmes, recortes de jornais, gravações e, em especial, entrevistas realizadas por eles mesmos, compondo um rico mosaico em que o passado - capturado por meio de versões e percepções - é tensionado por narrativas outras, agora do presente, num interminável jogo de readequações e (re)inscrições. Afinal, todo ato memorialístico institui-se por meio de jogos temporais, pois articula acontecimentos e circunstâncias do passado, motivações e reenquadramentos ativados no presente e intencionalidades futuras - sejam as motivações de fundo moral, político, estético ou de outra natureza.

Para esta discussão, valemo-nos de noções e conceitos como memória individual, memória social e memória histórica, nas relações e contraposições que Halbwachs (2006) estabelece entre elas. Também as reflexões de Michel Pollack (1992) sobre as relações entre memória e identidade social mostraram-se essenciais para nosso trabalho analítico, pois a leitura do corpus empírico indicou-nos, enfaticamente, o que se entendeu serem intencionalidades dos relatos memorialísticos em fazer fruir de suas narrativas a percepção do poder da música popular na constituição de identidades e identificações espaço-temporais. Talvez, mais até, o de como a própria sociedade brasileira - no senso comum tida como uma cultura marcadamente musical - embalou sua própria história ao som do glamour e romantismo do samba-canção, do minimalismo da bossa-nova, das paixões agudas do sertanejo e das desilusões e rejeições amorosas e traições que substanciam o gênero brega/cafona. Por fim, a noção de agenciamentos da memória mostrou-se uma perspectiva fundamental pois

22 ALCEU - v. 18 - n. 36 - p. 21 a 35 - jan-jun. $/ 2018$ 
nos possibilitou perceber que inscrições memorialísticas, como as que nos dedicamos a analisar neste artigo, resultam de tentativas de enquadramentos e angulações dos acontecimentos de épocas específicas da vida social brasileira em que acabam por prevalecer, muitas vezes, sentidos morais ou estéticos, que vão se definindo em função dos vieses e tons buscados pelos autores das obras.

\section{Agenciamentos da memória pela música}

Pollack (1992), baseando-se em Halbwachs, salienta que a memória deve ser entendida, também, como um fenômeno coletivo e social, "construído coletivamente e submetido a flutuações, transformações, mudanças constantes" (Pollack, 1992: 201). E se o passado nunca está, afinal, concluído, o ocorrido ou pretensamente ocorrido resulta de constantes tensionamentos e disputas de sentido. Ou como afirma Michel Pêcheux, a memória "é necessariamente um espaço móvel de divisões, de disjunções, de deslocamentos e de retomadas, de conflitos de regularização (...). Um espaço de desdobramentos, réplicas, polêmicas e contra-discursos”. (apud Achard, 2007: 56).

Para Pollack, os elementos constitutivos da memória, individual ou coletiva, são os acontecimentos, personagens e lugares - vividos pessoalmente ou "por tabela", ou seja, vividos e repassados pela comunidade à qual a pessoa pertence. (Pollack, 1992: 202). Segundo o autor, tais elementos, experimentados direta ou indiretamente, podem referir-se a circunstâncias reais, mas podem também tratar-se de projeção de outros eventos, resultantes da imaginação e projeções de desejos e fobias - o que ocorreria aí seriam transferências e projeções. Cabe aqui certamente uma associação aos estudos de Bakhtin (2003), sobre o romance biográfico, quando o autor russo explana sobre o tempo biográfico. Bakhtin destaca que o tempo biográfico tem que estar sediado no tempo histórico, uma vez que a vida biográfica "é impossível fora de uma época, cuja durabilidade, que vai além de uma vida única, é representada, antes de tudo por gerações. (...) As gerações (...) introduzem os contatos de vidas de tempos diferentes". (Bakhtin, 2003: 214-215).

Essa perspectiva bakthiniana reforça a hipótese de que a música - seus agentes e contextos de produção e circulação - pode mesmo instituir-se como potente vetor da memória social, a partir de agenciamentos materializados por relatos memorialísticos em que os jogos memória/esquecimento; sucesso/fracasso; previsível/trágico são, de modo retroalimentador, substância, a montante e a jusante, dos atos memorialísticos e, ao mesmo tempo, compõem e fazem movimentar, de modo ativo, as engrenagens dos processos e negociações da composição da memória.

De modo sucinto, como convém à extensão deste artigo, cabe dizer que entre o processo de autonomização do músico como artista e profissional e a transformação da própria música, que passou a ser apresentada em teatros, cabarés e os novos music halls, como produto comercial e não mais restrito exclusivamente à nobreza, 
foi preciso pouco mais de um século. Já no final do século XIX, surgiu em vários países uma relevante produção musical que já ensaiava passos para a constituição de um forte mercado consumidor de entretenimento. No campo da música, editoras em praticamente toda a Europa passaram a publicar partituras, livros e revistas especializadas no universo musical. E ao mesmo tempo em que a música continuava sendo considerada elemento constitutivo e de distinção do ideário da cultura das classes dominantes, as composições e artistas de origem mais humilde passaram a reescrever a própria concepção da música como expressão cultural e valor social. Ou como destacam Vianna e Bruck:

Na primeira década do século XX, com o advento dos meios técnicos de captação e reprodução do som, estas alterações ganham novo caráter. Se é que ainda persistia, esta "aura" começa a rarear-se e a desfazer-se ainda mais. A música clássica deixou de ser um privilégio da aristocracia e a música popular passou a alcançar um número de pessoas muito maior que os pequenos grupos de audições informais. O microfone, que amplifica a voz e os instrumentos, o disco e, posteriormente, o rádio passam a levar este som amplificado para as residências, possibilitando também o aumento da quantidade de pessoas que ouvem música. A reprodução técnica aproximou, assim, a obra de um público agora amplo, anônimo e menos qualificado para a compreensão daquelas peças artísticas mais complexas. (Vianna; Bruck, 2008: 178).

Fato é que já nas primeiras décadas do século XX, a música ganhou contornos ainda mais complexos de produção e distribuição. As novas possibilidades para sua agora exponencial reprodutibilidade técnica aceleraram os passos da internacionalização de gêneros e de transposição de fronteiras. Na música brasileira, Carmen Miranda (1909-1955) talvez seja a artista que mais enfaticamente simbolize o deslocamento da música experimental/artesanal para o processo industrial e prevalentemente comercial. Carmen, aliás, parece ter vivido como poucos artistas de sua época, tal situação. A começar pelo sucesso financeiro que alcançou nos Estados Unidos - possível graças a intermináveis maratonas de gravações de discos e filmes e shows, muitos shows. Castro (2005) aponta que Carmen talvez tenha sido uma das primeiras artistas do mundo da música a ser liquidificada pela indústria das gravadoras e dos espetáculos:

Carmen não parava porque não era possível parar - porque havia um contrato a cumprir e um avião a tomar, e uma plateia pronta para ouvir "mamãe, eu quero" e a rir com a histórica do cabelo, e talvez porque fosse melhor estar na estrada do que em casa. (Castro, 2015: 497).

24 ALCEU - v. 18 - n.36 - p. 21 a 35 - jan-jun./2018 
Eram quase quinze anos de um processo longo e inexorável. Começara no dia em que uma cápsula para dormir exigira outra para acordar. Tempos depois, a cápsula para dormir exigira outras cápsulas para dormir, e a cápsula para acordar, outras cápsulas para acordar. Um drinque cancelara uma cápsula e exigira outra cápsula. Essa cápsula cancelara o drinque e exigira outros drinques. Em meio à ciranda, as cápsulas e o drinque haviam cancelado uma quantidade de neurônios e, apesar dos recentes esforços de seu médico no Rio, Carmen já não sabia onde ficava a entrada ou a saída do infernal labirinto em que sua vida se convertera. (Castro, 2015: 541).

Carmen Miranda e tudo o que ela representou protagonizaram no início da década de 1930 no Brasil o que se pode chamar de período embrionário da indústria fonográfica e da própria indústria do entretenimento. Uma gestação intensa e profícua. Ainda em fase incipiente de industrialização e urbanização, o País já possuía, naquela época, uma movimentada produção fonográfica. Um exemplo é o da própria Carmen que, ainda em início de carreira, mas já com notório reconhecimento público, gravou, em pouco mais de um semestre do ano de 1930, para a Victor, 28 músicas, ou seja, catorze discos.

Boa parte dessa história e dessas histórias saltam dos relatos memorialísticos de Alonso, Araújo e Castro. E tais leituras levaram-nos ao entendimento de que se os estilos e movimentos musicais que esses autores "biografam" são os personagens principais de suas escritas, não menos importante são os lugares e acontecimentos (Pollack, 1992) por meio dos quais fazem surgir as histórias que, nos agenciamentos que propõem, oferecem uma visada organizadora e articuladora de origens, causas e efeitos e mesmo uma linearidade harmonizante da época retratada.

Como se dirá à frente, há importantes distinções entre essas narrativas. Castro em Chega de saudade (1990) e $A$ noite do meu bem, para além da inscrição da memória, faz de seus romances memorialísticos - como o próprio autor os caracteriza - praticamente uma celebração, uma comemoração, no sentido etimológico da palavra, de rememorar juntos. "A noite no Rio não terminava nunca" (Castro, 2015: 44), salienta o autor, buscando trazer para as páginas de seu livro sensações da agitadíssima noite carioca de inúmeros shows, boates, carteados, bebidas, mas, especialmente, muito vinculada ao exercício do poder na antiga capital do País. Já Alonso se ocupa em tentar compreender como a música caipira, chamada de raiz e "genuinamente" do profundo da cultura regional e interior do Brasil, bifurcou-se, tão rapidamente, sendo que um dos caminhos deu origem a um avassalador produto de consumo, que passou a ser denominado de música sertaneja. Tal oposição se apresenta logo nas primeiras linhas do livro, quando Alonso compara o pouco prestigiado e modesto velório de João Pacífico, autor de "verdadeiros clássicos" da música de raiz e o velório do cantor sertanejo Leonardo, que moveu e mobilizou multidões para homenageá-lo. (Alonso, 2015). 
Porém, a mais relevante dissonância que se pode perceber em uma leitura transversal das obras se dá com Eu não sou cachorro não: música popular cafona e ditadura militar. Em determinadas passagens de seu livro, assumindo tom quase panfletário, Paulo César de Araújo insere em seu relato questionamentos e cobranças em relação ao modo como o gênero que ele mesmo nomeia de cafona e brega e também os músicos que lhe deram voz são submetidos a um apagamento, ao esquecimento. Araújo (2002) faz mais do que problematizar o que entende ser uma visão elitista e excludente da crítica e da mídia em geral e de grupos sociais em relação ao estilo brega. O autor arma-se de argumentos tentando provar que, a despeito de os próprios cantores bregas terem declarado em entrevistas ao pesquisador que eram alheios ao que acontecia na política brasileira nos anos 1960-80, na vigência do regime ditatorial, também eles, ao seu modo, foram contestadores e críticos da situação política, econômica e social vigente. Assim, Araújo reivindica lugares mais respeitáveis na memória coletiva (Nora, 1993) e na história (Le Goff, 1996) da MPB para as músicas bregas e seus artistas que "fazem parte da memória de milhões de ouvintes de rádios, de discos e de serviços de autofalantes”. (Araújo, 2015: 15).

\section{Esquecer para lembrar. Lembrar para esquecer}

Em Cowboys do asfalto (2015), Gustavo Alonso adota uma visada que se pretende mais processual, buscando, em seu relato, estabelecer origens, causalidades e consequências dos movimentos que percebe, e, com isso, desvelar as condições de natureza sociocultural e também econômica que levaram a música caipira, considerada genuína, matricial da própria cultura e regional por excelência, ícone de um Brasil "verdadeiro", a desembocar no que, no início dos anos 1960-70, passou a ser denominado de sertanejo e suas variações: breganejo, sertanejo-universitário, entre outros - um produto essencialmente comercializado e cevado de influências estrangeiras como a guarânia, o bolero, entre outros.

À medida que se avança na leitura de Cowboys do asfalto (2015), o leitor se depara com aspectos que são instigantes e muitos dos acontecimentos e circunstâncias que o autor traz à lembrança podem, eventualmente, surgir para o leitor como novidade, ou porque este os havia esquecido ou porque nunca os conhecera. E nessas complexas operações de acionamento da memória, o jogo lembrar-esquecer- lembrar faz com que o olvido ou não sabido redimensionem não apenas o passado, mas, de algum modo, reinventem o presente. Pode-se mencionar como exemplo o modo como o historiador desconstrói a lembrança do que teria sido a acirrada polarização entre a música sertaneja e caipira. A ideia, tenta demarcar Alonso, de que houve um confronto original e acirrado entre caipiras (puros, enraizados e verdadeiros) e sertanejos (que ofereciam um produto essencialmente comercial, representantes de uma falsa cultura interiorana) não corresponde ao que seria a 
verdade dos fatos. O autor nos convida a esquecer tais percepções, para que se possa instituir uma memória correta do que se passou.

Para Alonso, talvez o mais importante embate da história da música brasileira tenha se dado em torno da adesão dos estilos "nacionais" às influências estrangeiras, especialmente com a popularização do rádio, que contribuiu para a importação de gêneros musicais "como o jazz americano e gêneros caribenhos como o mambo, a conga e o bolero. Também a guarânia paraguaia, o rasqueado mexicano e o chamané argentino atravessaram as fronteiras". (Alonso, 2015: 35) O sertanejo, que cada vez mais se aproximou das grandes cidades, foi influenciado, especialmente, pelos sons latinos. E tal conflito teria ocorrido não apenas no surgimento do sertanejo comercial - em contraposição ao "purismo" da música rural - mas em outros momentos como o da bossa-nova, e seu forte namoro com o jazz; a jovem guarda e o "rock iê-iê-iê" de Roberto Carlos; o tropicalismo e a discussão em torno da aceitação da guitarra e das baladas pop como "parte constitutiva da música brasileira". (Alonso, 2015: 60).

Os contextos políticos foram também modalizadores e influenciaram os rumos da música popular no Brasil. À época da ditadura, por exemplo, os posicionamentos assumidos pelos músicos estabeleceram, inevitavelmente, aproximações e afastamentos entre os artistas em função de grupos de interesse e opções político-ideológicas. Entre os vários efeitos dessa divisão, pode-se citar a aproximação que se verificou entre caipiras e os cantores e o público da MPB, e, ao mesmo tempo, o distanciamento de ambos em relação a outro tipo de música que também vinha do interior do País, agora já denominada sertaneja, fortemente influenciada pelos ritmos latinos.

A ideia que os artistas da MPB faziam do interior do Brasil era de que o campo estaria prestes a explodir numa onda revolucionária contra os ditadores. Assim, cantar o interior era associar pureza estética e espírito revolucionário. (...) Ou seja, houve então uma conjunção de interesses estéticos entre caipiras e artistas e público da MPB. Esse encontro é muito importante para se compreender a vitalidade do discurso nacional-popular desse gênero e as dificuldades de incorporação dos sertanejos. Foi também a partir da entrada da MPB no debate da música rural que se consolidou a distinção entre as músicas caipira e sertaneja. A MPB viu nos caipiras a "autêntica" representação do campo e desprezou os sertanejos por esses aceitarem a incorporação do som estrangeiro. (Alonso, 2015: 43).

Se o lado mais "autêntico" da MPB se associava ao caipira, por assim também considerá-lo, os sertanejos logo perceberam que tinham forte aceitação pelo grande público e intensificaram a incorporação de influências estrangeiras e, com elas, muitos 
shows e vendas de discos. E as primeiras duplas sertanejas, antes restritas a pequenos shows em circos, churrascarias e coretos de cidades do interior, passaram a ganhar cada vez mais espaço na mídia e transpuseram as fronterias do interior. Pode-se dizer que nos anos 1970, as duplas Léo Canhoto \& Robertinho e Milionário \& José Rico abriram, definitivamente, a estrada da nova vida do sertanejo moderno, que passou a ser conhecido nacionalmente e vender milhões de discos.

A partir dos anos 1980-90, a música sertaneja - que de vez assumiu as mesclagens do rock, do próprio caipira, do romântico e do que mais pudesse se tornar sucesso de vendas - buscou alcançar uma identidade para si, fortemente caracterizada pela cultura da mixagem e remixagem, tão própria do mundo contemporâneo. Alonso (2015) destaca, ainda, a importância que tiveram, na construção dessa aceitação, os relatos biográficos dos cantores sertanejos. Nessa nova fase, o filme Os 2 filhos de Francisco parece ser a maior expressão. Assistido por mais de cinco milhões de pessoas, o filme que conta a vida e a carreira dos irmãos Zezé Di Camargo e Luciano, toca, como destaca Alonso, num tema muito presente nas discussões sobre a essência da música brasileira: a autenticidade cultural. E no caminho reaberto por Zezé Di Camargo e Luciano, muita gente veio logo atrás, (re)contando sua história: Leandro e Leonardo, Chitãozinho e Xororó, Daniel, Victor \& Leo produziram documentários, seriados televisivos, song-books em que narram sua história.

O discurso da autenticidade, ou como destaca Alonso, a "recaipirização" do sertanejo, parece ter selado a paz entre os sertanejos e a MPB - realinhamento definido, certamente, por interesses comerciais. O autor avança até o fim da primeira década do século 21, marcada pelo surgimento do sertanejo universitário. É, certamente, como destaca Alonso, mais uma variação de tantas outras variações, só que agora numa hibridização sem limites, ao beber além das influências estrangeiras, nas fontes do forró, do axé, do arrocha e muito mais - tudo "junto e misturado" (Alonso, 2015: 406).

\section{O samba-canção e a bossa nova de Ruy Castro}

Compreendendo seus relatos memorialísticos sobre o Rio de Janeiro dos anos 1940, 1950 e 1960 como romances, Ruy Castro apresenta ao leitor uma visão da noite carioca como uma festa sem fim. Tanto em Chega de Saudade (1990) quanto em $A$ noite do meu bem (2015), o autor privilegia a memória do que teria sido uma época de ouro da vida musical brasileira, a partir de um olhar sobre a movimentada vida social e cultural do eixo Rio-São Paulo, pelo viés da boemia, dos inferninhos, das vidas de artistas já famosos ou ainda se despontando, e todos eles cheios de manias, arrogâncias, mas também fraquezas - perfis acionados por intermédio de relatos de quem diretamente conviveu com eles ou nem eram tão próximos assim, mas, em ambos os casos, como aponta Pollack (1992), experimentados por tabela. 
Noite adentro e noite afora, os romances de Ruy Castro inventariam a vida noturna carioca e, literalmente, mapeiam as casas de shows mais famosas do Rio de Janeiro - durante e depois dos cassinos. São narrativas recheadas de memórias que se sobrepõem, se entrecruzam em "história e histórias" (Castro, 1990; 2015) sobre paixões, traições, amores não correspondidos, dinheiro, poder político, tráfico de influências - tudo ao som dos sambas-canções nos cassinos e, depois de 1946, com a proibição dos jogos de azar, nas boates e inferninhos que criaram uma cultura muito própria da noite da então capital federal. Um cenário que se mostrou fecundo para o surgimento do gênero musical que, mais à frente, embalou o sonho de um novo Brasil, pós Getúlio Vargas - moderno, industrializado e urbano: a bossa-nova.

Em Chega de saudade (1990), a bossa nova é a grande personagem e seu surgimento e sucesso são materializados nas aventuras, desventuras, manias e outros episódios rocambolescos de artistas como João Gilberto, Ronaldo Bôscoli, Nara Leão, Carlinhos Lyra, Tom Jobim, entre tanto outros. Mas o grande destaque do livro, inevitavelmente, é João Gilberto, com seu jeito introvertido e controverso. Castro, na apresentação do romance, assume que o relato a ser lido "tendo sido escrito por alguém que vem ouvindo Bossa Nova desde que ela ganhou este nome, (...) uma certa dose de paixão acabou se intrometendo na receita - sem interferir, espero, pró ou contra, na descrição da trajetória de qualquer personagem”. (Castro, 1991: 15) E Chega de saudade se constrói, principalmente, de casos, passagens, detalhes de encontros, bebedeiras, despojados flâneurs noturnos, puxados da memória de pessoas que, direta ou indiretamente, participaram do movimento, em mais de 100 entrevistas realizadas por Castro.

A trama transporta o leitor para um Brasil pós-guerra, mas suas ações se localizam numa atmosfera muito específica: a do Rio de Janeiro do princípio dos anos 1950. Castro frisa que o movimento da bossa-nova foi puxado por jovens entre 15 e 30 anos de idade. apaixonados pela música e seduzidos pelo jazz, que, afinal, está no DNA da bossa-nova. E o caminho construído por Castro é de recuperação desse DNA, ou seja, como exatamente a bossa-nova começou. Cabe lembrar que o trabalho iniciado em Chega de Saudade, que teve primeira edição em 1990, foi aprofundado em Carmen - primeira edição em 2005 - e rendeu ainda ao autor a possibilidade de publicar $A$ noite do meu bem (2015) - que se propõe ser a memória do samba-canção e da época de glamour das noites cariocas.

"Mas para que houvesse o samba-canção, foi preciso que houvesse o samba, e ele só se estratificou na segunda metade dos anos 1920" (Castro, 2015: 71), assinala Ruy Castro em $A$ noite do meu bem. O autor associa, de algum modo o "amaciamento" do samba no Brasil a um aspecto técnico - o surgimento da gravação elétrica em substituição à gravação mecânica. E se já havia o choro-canção, o tango-canção e a valsa-canção, o surgimento do samba-canção foi um passo curto. Há o consenso de que o gênero surgiu bem no finalzinho da década de 1920, com a composição de 
Henrique Vogeler Linda Flor, lançada em 1929 e que, posteriormente, ficou popularmente conhecida como $A$ i, ioiô. (Castro, 2015).

O samba-canção deu novas roupagens e institucionalizou no asfalto o ritmo que já há muito saltava dos morros e vilas das cidades. Mas, agora, numa versão comportada, romântica e suavemente dançante. É exatamente esse clima de uma boemia glamourizada, chique e torrente de vidas excepcionais que Castro quer fazer fruir. $\mathrm{E}$ para isso matéria prima não lhe faltou: a capital federal dos anos 1940 e 1950, que já se eternizava pelo charme das praias, boa música e noites sem fim, tinha como recheio personagens reais talvez até mais insólitos e dramáticos que aqueles presentes nas letras das músicas que compunham. Os registros de Castro adotam como estratégia narrativa a recuperação do momento, do acontecimento, a cena desimportante que se perdera. Tem forte vocação descritiva e cênica, como, entre tantos exemplos, o trecho da ida de Linda Baptista para a Europa, depois de despedir-se, na última hora, no Palácio Rio Negro em Petrópolis, de Getúlio Vargas (com quem supostamente teve um caso). O efeito de real parece aqui garantido pelo modo de recuperação dos pequenos fatos, por meio dos quais, o autor rememora o caso e alimenta a versão de um possível romance entre o presidente e Linda Baptista.

Linda olhou para o relógio e viu que estava atrasada para o voo. Àquela hora, já deveria estar no Galeão. Getúlio lhe disse que ficasse tranquila. Despediu desejando-lhe felicidades e destacou dois batedores para abrir-lhe caminho serra abaixo e até o aeroporto. Linda, excelente motorista, fez todas as barbaridades possíveis na estrada sem ser incomodada e chegou a tempo para o voo. (Castro, 2015: 196).

Merece registro ainda um trecho de $A$ noite de meu bem que denota a forte dimensão midiática que cedo tomou a vida dos artistas da música popular no Brasil. Castro (2015) traz à memória a verdadeira guerra conjugal que se estabeleceu entre Dalva de Oliveira e Herivelto Martins, no ano de 1947, e que ganhou as colunas de jornais, programas de rádio e mesmo textos assinados por Herivelto Martins e publicados na revista Escândalo e no jornal Diário da Noite, o que teria acontecido com as bênçãos do então poderoso repórter David Nasser, que, segundo Castro, gostaria de tê-los publicado, na verdade, na revista O Cruzeiro. Mas Dalva e Herivelto foram bem além. Por mais de um ano, ambos lançaram sucessivas músicas cujas letras abordavam as traições, surtos de ódio e mútuas agressões. Muitos desses sambas-canções conquistaram a ambicionada condição de permanência no cancioneiro nacional e receberam inúmeras regravações nas últimas décadas.

Desde Segredo ("Seu mal é comentar o passado"), Tudo acabado ("Tudo acabado entre nós. Já não há mais nada."), Errei, sim - de Ataulpho Alves até outras músicas como Perdoar e Fim de comédia. Na incipiente mas já intensa praça pública midiática, 
Dalva e Herivelto devassaram sua privacidade e mesmo intimidade, como quando tornaram públicos os detalhes de como Dalva de Oliveira o flagrou em sua própria cama com Isaurinha Garcia (Castro, 2015). E, claro, compositores, gravadoras e jornalistas alimentaram o quanto puderam o conflito entre os dois ao perceber que o caso vendia jornais, revistas e, principalmente, discos.

\section{O cafona, o brega e a ditadura: o grito de redenção de PC de Araújo}

No entendimento de Araújo (2015), houve três gerações da chamada música brega/cafona: a dos anos 1950-60 (composta por cantores como Anísio Silva, Orlando Dias, Silvinho, entre outros); a segunda geração, dos anos 1970 (Odair José, Fernando Mendes, Waldick Soriano etc), que é, de modo mais enfático, objeto de estudo do livro, e uma terceira geração, que se situaria no fim da década de 1970 e anos 1980 (cantores como Sidney Magal, Agepê, Amado Batista). Para o pesquisador, todas essas gerações de cantores cafonas nunca foram consideradas como pertencentes à "chamada MPB, que, mais do que um gênero de música, transformou-se, a partir do fim dos anos 60 , numa verdadeira instituição dotada de reconhecimento social e lugar social bem determinado". (Araújo, 2015: 32).

Ao adotar como título de seu livro um verso de uma música do contravertido cantor do estilo brega/cafona Waldick Soriano - "Eu não sou cachorro, não", Paulo César de Araújo deixa bem claro ao que veio. Daí para frente, são 375 páginas recheadas de delineamentos e argumentações, por meio dos quais investe na defesa do estilo brega/ cafona que, no seu entendimento, padece de injusta exclusão da historiografia musical e, mesmo quando lembrado, o é de modo estereotipado e preconceituoso.

Para o autor de Eu não sou cachorro, não, a visão hegemônica e a memória da qual resulta atuam de tal modo que o lado contestador dos compositores e cantores do estilo brega acaba por ser desconsiderado, o que impede que estejam no mesmo patamar de importância de outros nomes da MPB, entre outros, como os de Caetano Veloso, Chico Buarque e Gilberto Gil. Arrolando exemplos que aponta como comprobatórios, Araújo enfatiza que Odair José, Nelson Ned, Agnaldo Timóteo, Fernando Mendes, Waldick Soriano e tantos outros também foram, de modo explícito, questionadores do poder ditatorial vigente nos anos 1970-1980 e inclui entre esses artistas a dupla de irmãos Don e Ravel, que acabaram se fixando na memória e na história pela aproximação com os governos militares, com a gravação de músicas como Eu te amo, meu Brasil.

Um dos mais recorrentes argumentos de Araújo é que, assim como vários cantores da MPB, os bregas também foram vítimas de censura e de perseguição por parte da ditadura. Depois de ter a música $A$ primeira noite de um homem proibida, os censores teriam passado a observar Odair José mais de perto e a situação teria se agudizado com a música Pare de tomar a pílula. Segundo Araújo (2015), a canção atingia "aspectos de caráter político-social que incomodavam as autoridades do regime militar 
brasileiro (Araújo, 2015: 60). O autor narra o episódio em que, mesmo com a música proibida, Odair José, diante da insistência do público, decidiu cantá-la em um show. Acabou sendo detido pela polícia. Em seguida, saiu do Brasil e ficou uma temporada em Londres. Mas vinha sempre ao Brasil, não estando proibido de fazê-lo. Outros exemplos destacados em Eu não sou cachorro, são os dos cantores Waldick Soriano, Agnaldo Timóteo e Lindomar Castrilho. Waldick Soriano teve censurada a canção Tortura de amor (Hoje que a noite está calma/ E que minh'alma espera por ti ...). Improvável perceber na música qualquer sentido político, mas foi censurada porque trazia a palavra "tortura". Como pode se observar nos trechos a seguir, extraídos de Eu não sou cachorro, não, há, por um lado, uma reiterada busca pelo autor de um reposicionamento para os artistas do estilo brega e cafona:

(...) [Este trabalho] ao pesquisar a obra musical de uma geração de cantores/ compositores considerados "cafonas", visa recuperar a memória de uma facção da cultura popular deixada ao largo da historiografia, trazendo à tona sua luta, seus embates, suas formas de expressão e resistência. (Araújo, 2015: 23).

Não dá mais para dissimular ou esconder. A produção musical "brega" ou "cafona" é um fato de nossa realidade cultural e, assim como a da bossa nova ou do tropicalismo, precisa ser pesquisada e analisada. (...) através da análise da produção daconstrução social da memória é possível identificar de que maneira ficou cristalizada em nosso país uma memória da história musical que privilegia a obra de um grupo de cantores/compositores preferido das elites, em detrimento da obra de artistas mais populares. (Araújo, 2015: 15-16).

Por outro lado, o autor enumera em seu livro vários exemplos de artistas não percebidos como do estilo brega que, à época da ditadura, estiveram próximos ou apoiaram explicitamente o então presidente Garrastazu Médici e o governo militar ditatorial. De modo assinalado, poupando apenas Chico Buarque, "um notório opositor", PC de Araújo destaca que outros músicos como Jorge Ben Jor, Ivan Lins, Wilson Simonal, Roberto Silva, Sílvio Caldas, Zé Ketti, João Nogueira, entre tantos outros, compuseram músicas, fizeram shows e mostraram-se simpáticos ao governo - o que, para o autor, atesta que durante a ditadura houve um "vendaval ufanista (...) que arrastou mais artistas da MPB que transitavam pelos círculos de esquerda”. (Araújo, 2015: 121).

\section{Considerações finais}

Esta reflexão surgiu da observação de que a memória social (Pollack, 1992) da música no Brasil, para a qual contribuem, entre tantos outros elementos, relatos memorialísticos como os livros aqui analisados, partem de perspectivas e compreen- 
sões tão distintas que poder-se-ia afirmar que chegam a estabelecer sentidos diversos, quando não contraditórios, para os mesmos episódios, circunstâncias e personagens. Importante considerar que tais relatos, conformados por projetos de busca e designação (escrita), desenvolvem-se a partir de formas bem próprias de agenciamento do memorável, ou seja, uma articulação em torno de recortes e como os mesmos são observados e interpretados e os modos como, na transversalidade do relato, tecem-se os sentidos que fazem emergir o entendimento proposto ao leitorado pelo autor - o que, de algum modo, também revela os interesses e intenções do memorialista.

Nos quatro trabalhos dos três autores analisados, independentemente de suas estratégias narrativas e possíveis intencionalidades, o que se observa é que prevalece, ao final, a emergência da expressão de uma síntese, de um conjunto orientado e coerente por meio do qual se afirma o fato rememorado, que transcorre numa ordem cronológica, mas que também é sua ordem lógica. A opção teórico-metodológica de nos valermos de uma perspectivação baseada no que aqui denominamos de agenciamentos da memória, levou-nos a considerar que os autores analisados tendem a estabelecer para o conjunto de seu relato tal estratégia, denotada pela busca de uma linearidade narrativa a que os autores parecem ser tangidos - uma coerência e linearidade que, afinal, revelam-se sempre ilusórias (Bourdieu, 1996).

As reflexões desenvolvidas neste trabalho buscaram dar uma contribuição para questões que consideramos relevantes acerca dos agenciamentos da memória como modo de compreensão da vida social: É possível que a memória conviva com contradições ou a condição de verdade linear e monolítica lhe é condição pressuposta e imprescindível? Sobrevive a memória em meio à dúvida, ou questionamentos e imprecisões não conseguem penetrar nos campos do memorável?

Em relação aos relatos de memória, pode-se afirmar, a priori , que as sínteses coerentes, linearmente bem arranjadas e autoexplicativas parecem se fixar melhor e tendem a sobreviver mais no tempo como memoráveis. Assim como parece correto afirmar que uma das circunstâncias requeridas pela memória é essa estabilidade mínima dos elementos que a constituem nos alongados processos de sua configuração - que lhe são definidores - e que fazem surgir de um conjunto complexo e dinâmico de acontecimentos, imagens e circunstâncias, sintetizadas percepções que vão, ao longo do tempo, se decantando e se firmando de modo prevalente. Até que novos elementos e processos se conjurem, de modo dinâmico e interminável, para redesenhá-la.

Mozahir Salomão Bruck

Professor da Pontifícia Universidade Católica de Minas Gerais (PUCMinas) Doutor em Literaturas de Língua Portuguesa (PUCMinas/Universidade Nova de Lisboa)

Recebido em setembro de 2017.

Aprovado em fevereiro de 2018. 


\section{Notas}

1. Segundo Castro, em 1944, Carmen Miranda foi a mulher que mais ganhou dinheiro nos Estados Unidos - "talvez até no mundo" (Castro, 2005: 406). Naquele ano, apenas 36 pessoas faturaram mais que Carmen nos EUA, considerando-se todas as atividades econômicas indústria automotiva, petróleo, setor financeiro etc.

2. Gustavo Alonso (2015) assinala que, até os anos 1930, as músicas do interior do país eram, sem distinção, denominadas de sertanejas. Outro fato relevante é que este tipo de música não possuía ainda um reconhecimento nacional. Pelo contrário, era considerada uma música regional, mais precisamente regional do interior de São Paulo.

3. Estrada da vida, do diretor Nelson Pereira dos Santos, de 1979, foi o primeiro filme biográfico de músicos sertanejos que alcançou sucesso. Contando a trajetória da dupla Milionário \& José Rico, o filme foi ofertado para 15 países, alcançando principalmente sucesso entre os chineses.

\section{Referências}

ACHARD, Pierre et al. Papel da memória. Campinas, Pontes Editores, 2007.

ALONSO, Gonçalo. Cowboys do Asfalto. Rio de Janeiro: Civilização brasileira, 2015.

ARAÚJO, Paulo César de. Eu não sou cachorro não. 9.ed. Rio de Janeiro, Record, 2015.

BAKHTIN, Mikhail. Estética da criação verbal. São Paulo, Martins Fontes, 2003.

BLANNING, Tim. O triunfo da música. São Paulo, Companhia das Letras, 2011.

BORDIEU, Pierre. A ilusão biográfica. In: FERREIRA, Marieta de Moraes e AMADO, Janaína (Org). Usos e abusos da história oral. Rio de Janeiro: Editora da FGV. p. 181-191.

CASTRO, Ruy. A noite do meu bem. São Paulo, Companhia das Letras, 2015 . Carmen. São Paulo, Companhia das Letras, 2005.

Chega de saudade. São Paulo, Companhia das Letras, 1991. $2^{\text {a }}$ Ed.

HALBWACHS, Maurice. A memória coletiva. São Paulo, Centauro, 2006.

HERSCHMANN, Micael (org). Nas bordas e fora do mainstream musical. São Paulo, Editora das Letras e Cores, 2011.

LE GOFF, Jacques. História e memória. 7.ed. Campinas: Ed. Unicamp, 2013.

NORA, Pierre. Entre memória e história: a problemática dos lugares. In: Projeto História, n.10, São Paulo, dez. 1993, p.7-28.

POLLACK, Michel. Memória e identidade social. In: Estudos Históricos. Rio de Janeiro, Vol. 5, 1992, p. 200-212.

VIANNA, Graziella M. e BRUCK, Mozahir S. Música e técnica, arte e reprodutibilidade 70 anos depois, apontamentos sobre as reflexões de Benjamin sobre arte e técnica. In: MEDITSCH, Eduardo. Teorias do Rádio. Florianópolis: Insular, 2008. 


\title{
Resumo
}

O artigo propõe reflexões sobre formas de agenciamento da memória da música brasileira como modo de compreensão da vida social, a partir da análise de quatro livros que se dedicam à história da MPB. A aproximação das obras Chega de saudade e $A$ noite do meu bem (Ruy Castro), Eu não sou cachorro, não (Paulo César de Araújo) e Cowboys do asfalto (Gustavo Alonso) busca perceber como tais autores articulam aspectos da memória social, enredando um diversificado leque de fontes documentais, em especial, entrevistas realizadas por eles mesmos, compondo um rico mosaico em que o passado - capturado por meio de versões e percepções - é tensionado por narrativas outras, agora do presente, num jogo de readequações e (re)inscrições. Entre os operadores conceituais convocados para este texto, destacamos as noções de memória social, as relações entre memória e identidade social (Pollack, 1992), memória coletiva (Le Goff, 2013) e as distinções sobre a memória assinaladas por Halbwachs (2006).

\section{Palavras-chave}

Memória. Agenciamentos. Narrativas. Música popular brasileira.

\begin{abstract}
The article proposes to reflect about forms of agencing of the Brazilian music memoryas way of understanding the social life, from the four books analysis dedicated to the history of MPB. The approach of Chega de Saudade and A noite do meu bem (Ruy Castro), Eu não sou cachorro, não (Paulo Cesar de Araujo) and Cowboys do Asfalto (Gustavo Alonso) seeks to understand how these authors articulate aspects of social memory, entangling a wide range of documentary sources, in particular, interviews by themselves, forming a rich mosaic in that the past - captured through versions and perceptions - is stressed by other narratives, now in present, in a game readjustments and re-inscriptions. Among the invited conceptual operators for this text, we highlight the notions of social memory, the relationship between memory and social identity (Pollack, 1992), collective memory (Le Goff, 2013) and distinctions on the memory indicated by Halbwachs (2006).
\end{abstract}

\section{Keywords}

Memory. Agencings. Narratives. Brazilian popular music. 